\title{
FORMULASI TABIR SURYA ZINK OKSIDA DALAM SEDIAAN KRIM DENGAN VARIASI KONSENTRASI EKSTRAK ANGGUR HITAM (Vitis vinivera L.)
}

\author{
Joni Tandi*, Kurnia Gatot Novrianto \\ Program Studi S1 Farmasi, STIFA Pelita Mas Palu \\ *Corresponding author email: stifapelitamaspalu@yahoo.com
}

\begin{abstract}
ABSTRAK
Senyawa tabir surya yang umum digunakan adalah bahan sintesis, akan tetapi kadangkala bahan sintesis ini dapat menjadi berbahaya bila terserap ke dalam aliran darah. Untuk menghindari dampak negatif tersebut dapat digunakan tanaman obat tradisional, salah satunya anggur hitam. Telah dilakukan penelitian dengan tujuan untuk mengetahui seberapa besar efektivitas nilai SPF tabir surya yang diberikan oleh ekstrak anggur hitam sebagai factor pelindung sinar matahari terhadap kulit. Penelitian ini dilakukan dengan cara mengekstrak anggur hitam dengan metode maserasi bertingkat untuk menarik komponen kimia sebagai senyawa tabir surya. Ekstrak dibuat dalam empat konsentrasi kemudian diukur serapannya menggunakan spektrofotometer UV-Vis pada panjang gelombang $280 \mathrm{~nm}$ sampai $400 \mathrm{~nm}$, selanjutnya dihitung SPF. Hasil penelitian menunjukkan dari semua konsentrasi ekstrak anggur hitam memberikan nilai SPF yaitu pada konsentrasi $0 \% 2,33$, konsentrasi $0,4 \%$ 2,38, konsentrasi $0,8 \%$ 2,48 dan konsentrasi 1,2\% 2,53. Dari hasil ini dapat disimpulkan bahwa ekstrak anggur hitam mempunyai efek tabir surya karena nilai SPF yang diperoleh masuk dalam range syarat tabir surya yaitu 2 sampai 60 .
\end{abstract}

Kata Kunci : Vitis vinivera L, Tabir surya, Spektrofotometer dan SPF.

Submitted on:4 April $2017 \quad$ Accepted on: 9 July 2017

DOI: https://doi.org/10.25026/jsk.v1i7.72

\section{PENDAHULUAN}

Kosmetik dikenal manusia sejak 3500 Sm di Mesir. Pemakaian kosmetik mulai mendapat perhatian yaitu selain untuk kecantikan juga untuk kesehatan. Perkembangan ilmu kosmetik serta industrinya baru mulai secara besarbesaran pada abad ke-20. Perkembangan teknologi kosmetik tersebut begitu maju dengan pesat, sehingga menimbulkan perpaduan antara kosmetik dan obat yang disebut kosmetik medic. Kosmetik adalah bahan atau campuran bahan untuk digosokkan, dilekatkan, dituangkan, dipercikan atau disemprotkan, dimasukkan, dipergunakan pada badan atau bagian badan manusia dengan maksud untuk membersihkan, memelihara, menambah daya tarik atau mengubah rupa dan tidak termasuk golongan obat $[1,2]$.

Tubuh manusia yang sering berhubungan dengan kosmetik adalah kulit. Kulit adalah organ tubuh yang terletak paling luar dan membatasinya dari lingkungan hidup manusia, merupakan organ yang esensial, vital dan sebagai cermin kesehatan. Hal ini dapat dilihat dari fungsi kulit yang sehat yaitu mempunyai fungsi normal, tanpa kelainan atau penyakit. Secara klinis dapat dikategorikan halus, kencang, cerah, bebas penyakit, berfungsi baik, mempunyai toleransi optimal dan lembab. Aktivitas manusia yang sangat padat membuat kulit manusia harus bersentuhan dengan sinar ultra violet. $[8,10]$ 
Sinar ultraviolet dapat dipantulkan oleh berbagai benda di permukaan bumi sehingga besar kemungkinan pantulannya akan mencapai kulit kita, sehingga dapat menyebabkan penuaan dini pada kulit dan kanker kulit. Oleh karena itu dibuat kosmetik yang mengandung antioksidan yang dapat menyaring sinar ultraviolet bahkan yang dapat menahan seluruh sinar matahari untuk mengurang efek buruk sinar matahari tersebut. Ada dua macam komponen sinar ultraviolet yang mencapai bumi, yaitu UVA yang tidak akan membakar namun akan menembus ke dalam kulit yang bertanggung jawab terhadap penuaan dini dan kanker kulit dan UVB akan membakar lapisan kulit paling permukaan yang mengakibatkan kerusakan kulit akibat matahari yang jika terus menerus dapat menyebabkan kanker kulit. Kosmetik yang dapat mengahambat sinar UV A dan UV B adalah suatu sediaan krim yang mengandung antioksidan [9].

Tabir surya adalah kosmetik yang digunakan dengan maksud menyerap secara efektif cahaya terutama pada daerah emisi gelombang UV dan inframerah, sehingga mencegah terjadinya gangguan kulit karena cahaya matahari [3]. Anggur hitam mempunyai banyak manfaat. Khasiat yang paling banyak dicari adalah menjadi awet muda. Anggur hitam dapat mengatasi kelelahan dan hipoglikemik karena kandungan gula alaminya yang sangat tinggi terutama dalam bentuk glukosa, fruktosa, flavonoid, likopen dan karatenoid sebagai antioksidan alami. Anggur merupakan antioksidan alami yang dapat menangkal radikal bebas, sehingga dapat diformulasikan menjadi krim tabir surya [7]. Krim adalah bentuk sediaan setengah padat berupa emulsi yang mengandung satu atau lebih bahan obat terlarut atau terdispersi dalam bahan dasar yang sesuai dan mengandung air tidak kurang dari
$60 \%$. Sedangkan krim tabir surya adalah sediaan kosmetik yang digunakan untuk maksud membaurkan atau menyerap secara efektif cahaya matahari, terutama daerah panjang gelombang ultraviolet, sehingga dapat mencegah gangguan kulit yang disebabkan cahaya matahari. Tabir surya ada dua macam yaitu tabir surya organik yang bekerja secara kimiawi yaitu zat-zat aktif meresap sinar matahari dan melalui proses kimiawi merubahnya menjadi panas. Zat-zat yang bekerja dengan cara ini misalnya dioxybenzone, PABA oktil salisilat, avobenzone dan sebagainya dan tabir surya anorganik yang bekerja secara fisika yaitu dengan memantulkan cahaya matahari seperti zink oksid [13], [17], [18].

Penelitian ini bermaksud untuk mengetahui perbedaan yang signifikan antara variasi konsentrasi ekstrak anggur hitam sebagai tabir surya dalam menghasilkan mutu fisik krim tabir surya dengan menggunakan spektrofotometer pada panjang gelombang untuk UV A yaitu 320-400 nm dan UV B yaitu 290$320 \mathrm{~nm}$ dan tujuannya adalah untuk mengetahui dan memastikan bahwa ekstrak anggur hitam dapat diformulasikan menjadi krim tabir surya serta untuk mengetahui konsentrasi ekstrak anggur hitam yang paling efektif.

\section{METODE PENELITIAN}

\section{Alat dan Bahan}

Alat

Neraca analitik, mortir dan stamper, oven, rotavapor, spektrofotometer UVVis dan alat-alat gelas.

\section{Bahan}

Asam stearat, aquadest, cetacium, cera alba, gliserin, nipagin, nipasol, paraffin liquid, trietanolamin, 
zink oksida, asam oleat, kolesterol, lilin putih, minyak kelapa dan squalen.

\section{Prosedur Penelitian}

Menimbang dengan teliti 1 gram krim tabir surya ekstrak anggur hitam dengan variasi konsentrasi yang ada yaitu $0 \%, 0,4 \%, 0,8 \%$ dan $1,2 \%$ dengan tiga kali pengulangannya, kemudian dimasukkan dalam wadah film kemudian ditambahkan aseton $9 \mathrm{ml}$ lalu diaduk hingga larutan menjadi homogen. Lalu diaduk kembali dengan menggunakan magnetic stirrer untuk mendapatkan larutan yang lebih homogen. Setelah itu diukur absorbansinya pada panjang gelombang 280-400 nm dengan menggunakan spektrofotometer UV-Vis

\section{Analisis Data \\ Analisis yang digunakan untuk menguji mutu fisik krim tabir surya ekstrak anggur hitam ada dua yaitu dengan membandingkan hasil yang diperoleh dengan persyaratan yang tercantum dalam farmakope Indonesia dan pustaka lainnya. Analisis yang kedua adalah uji statistik dengan uji rancangan acak lengkap (RAL).}

\section{HASIL PENGAMATAN DAN PEMBAHASAN}

\section{A. Uji Spektrofotometri Krim Tabir Surya}

Tabel 1 Hasil Uji Spektrofotometri nilai SPF

\begin{tabular}{cccccc}
\hline Konsentrasi & \multicolumn{3}{c}{ Nilai SPF Ulangan } & \multirow{2}{*}{ Total } & \multirow{2}{*}{ Rerata } \\
\cline { 2 - 4 }$(\%)$ & I & II & III & & 2,33 \\
0 & 2,28 & 2,51 & 2,21 & 7,00 & 2,38 \\
0,4 & 2,38 & 2,39 & 2,39 & 7,16 & 2,48 \\
0,8 & 2,54 & 2,704 & 2,22 & 7,464 & 2,53 \\
1,2 & 2,55 & 2,68 & 2,38 & 7,61 & 9,72 \\
Total & 9,75 & 10,284 & 9,2 & 29,234 & \\
\hline
\end{tabular}

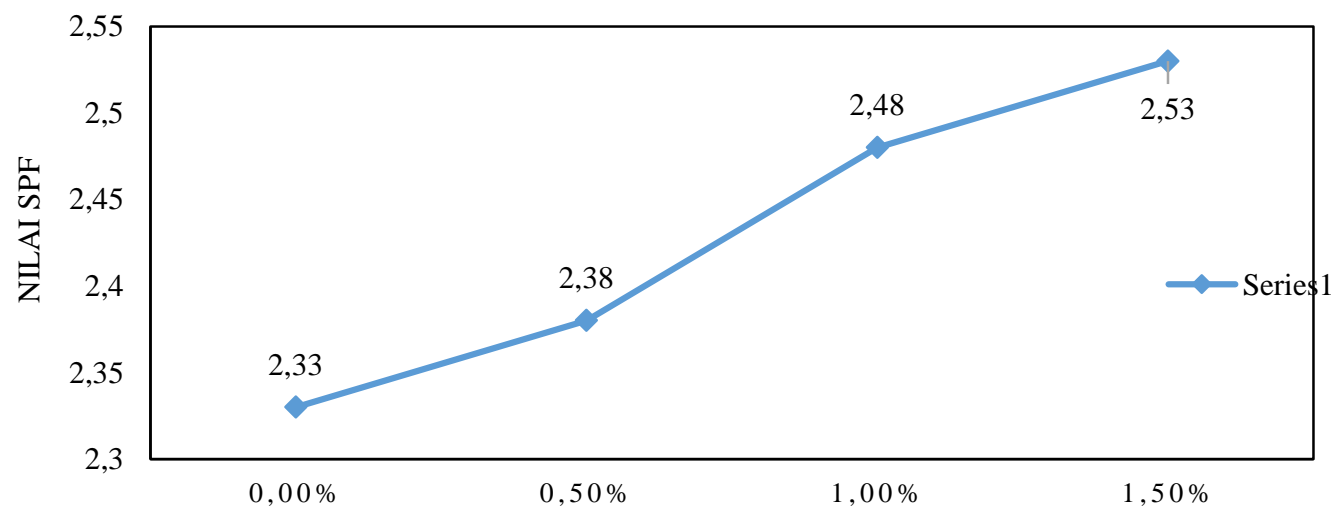

KONSENTRASI KRIM TABIR SURYA EKSTRAK ANGGUR HITAM

Gambar 1. Nilai SPF krim tabir surya ekstrak anggur hitam terhadap berbagai formulasi krim 
Formulasi Tabir Surya Zink Oksida Dalam Sediaan Krim Dengan Variasi Konsentrasi Ekstrak Anggur Hitam (Vitis Vinivera L.)

\section{B. Uji pH Krim Tabir Surya}

Tabel 2 Hasil Uji pH Krim Tabir Surya Ekstrak Anggur Hitam

\begin{tabular}{ccccc}
\hline \multirow{2}{*}{ Konsentrasi (\%) } & Waktu & \multicolumn{3}{c}{ Pengulangan } \\
\cline { 3 - 5 } & Penyimpanan (Hari) & I & II & III \\
\hline 0 & 0 & 5,2 & 5,22 & 5,24 \\
& 7 & 5,14 & 5,19 & 5,24 \\
\multirow{2}{*}{0,4} & 15 & 5,1 & 5,17 & 5,24 \\
& 0 & 5,07 & 5,12 & 5,28 \\
& 7 & 5,21 & 5,3 & 5,14 \\
\multirow{2}{*}{0,8} & 15 & 5,21 & 5,12 & 5,07 \\
& 0 & 5,25 & 5,35 & 5,27 \\
& 7 & 5,04 & 5,15 & 5,21 \\
\multirow{2}{*}{1,2} & 15 & 6,28 & 5,89 & 5,2 \\
& 0 & 5,03 & 5 & 5,31 \\
& 7 & 5,28 & 5,09 & 5,03 \\
& 15 & 5,25 & 5,05 & 5,4 \\
\hline
\end{tabular}

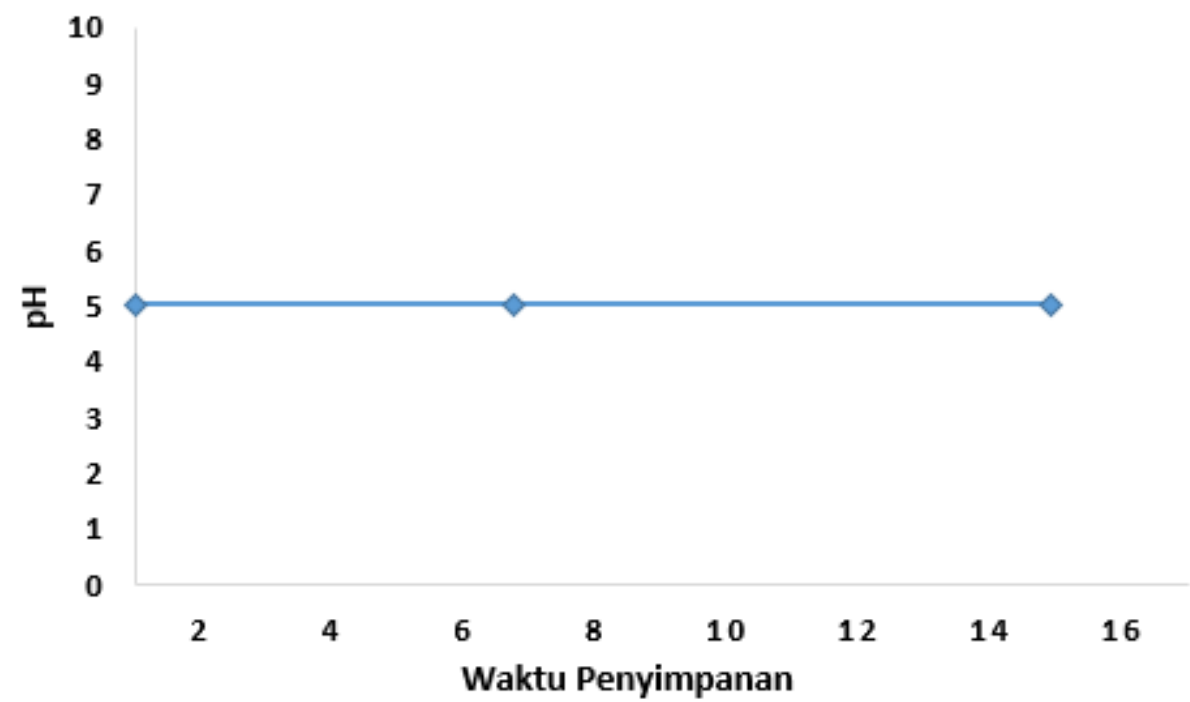

Gambar 2. Uji pH krim tabir surya ekstrak anggur hitam terhadap berbagai forrmulasi krim

\section{Uji Tipe Emulsi}

Tabel 3 Tabel hasil Uji Tipe Emulsi Krim Tabir Surya Ekstrak Anggur Hitam

\begin{tabular}{cc}
\hline $\begin{array}{c}\text { Formula Krim Tabir Surya } \\
\text { Ekstrak Anggur Hitam }\end{array}$ & Tipe Emulsi \\
\hline Formula $0,0 \%$ & $\mathrm{M} / \mathrm{A}$ \\
Formula $0,4 \%$ & $\mathrm{M} / \mathrm{A}$ \\
Formula $0,8 \%$ & $\mathrm{M} / \mathrm{A}$ \\
Formula $1,2 \%$ & $\mathrm{M} / \mathrm{A}$ \\
\hline
\end{tabular}




\section{Pembahasan}

Produk tabir surya bekerja pada permukaan kulit dan menyerap ultraviolet untuk menjadikan tidak berbahaya ataupun memantulkan cahaya ultraviolet. Saat kulit terkena sinar UV B merangsang produksi melanin, makin lama kulit makin terekspos sinar UV B maka kulit tidak mampu lagi untuk menghasilkan melanin dimana melanin berfungsi untuk menangkis sinar UV B yang diserap kulit, maka terjadilah sun burn atau terbakar matahari, guna menghindari sinar UV yang berlebihan maka digunakan tabir surya untuk menyerap sinar UV atau memantulkan sinar UV tersebut sebelum menembus kulit.

UV filter dapat diklasifikasikan menjadi 2 kelompok berdasarkan asalnya yaitu anorganik UV filter dan organik UV filter. Anorganik UV filter yang juga disebut UV filter fisik bekerja dengan memantulkan dan menghamburkan radiasi UV seperti zink oksida dan titanium oksida sedangkan organik UV filter yang juga disebut UV filter kimia bekerja dengan mengabsorbsi radiasi seperti PABA (Para-amino benzoic acid).

UV filter yang digunakan pada pembuatan krim tabir surya ini adalah zink oksida karena zink oksida merupakan tabir surya fisik yang paling efektif dan tidak bersifat karsinogenik karena mekanisme kerjanya yang memantulkan sinar UV sehingga aman untuk digunakan.

Krim tabir surya adalah sediaan kosmetik yang digunakan untuk maksud membaurkan atau menyerap secara efektif cahaya matahari terutama daerah gelombang ultraviolet sehingga dapat mencegah gangguan kulit dari cahaya matahari. Krim tabir surya ini menggunakan zat aktif yaitu ekstrak anggur hitam karena anggur hitam merupakan salah satu tanaman yang mengandung antioksidan.
Setiap sediaan Farmasi yang telah diproduksi harus melalui uji kualitas sediaan. Uji kualitas sediaan merupakan salah satu aspek yang harus dilakukan untuk mengetahui kualitas krim yang dihasilkan. Hal ini terkait kualitas atau mutu krim yang diharapkan. Secara umum uji atau control yang perlu dilakukan untuk sediaan krim menurut Farmakope Indonesia Edisi IV sebagai buku standar resmi yaitu : Uji viskositas, $\mathrm{pH}$ dan Uji organoleptik yang meliputi warna dan aroma.

Hasil uji Spektrofotometri krim tabir surya dilakukan untuk mengetahui nilai SPF yang terkandung dalam krim tabir surya ekstrak anggur hitam. Pada table 4.3 menunjukkan bahwa formulasi dengan kosnentrasi 1,2\% krim tabir surya ekstrak anggur hitam menunjukkan nilai SPF tertinggi dengan nilai 2,53 dibandingkan pada konsentrasi $0 \%, 0,4 \%$ dan $0,8 \%$. Hal ini menunjukkan bahwa semakin besar konsentrasi semakin besar pula nilai SPF yang diperoleh. Hal ini disebabkan karena kandungan zat aktif dengan kosnentrasi yang tinggi lebih banyak daripada konsentrasi yang rendah.

Uji penampakan fisik yang dilakukan pada penelitian adalah hanya mengamati perubahan warna dan aroma dari krim selama masa penyimpanan 2 minggu secara individual. Melalui pengamatan yang dilakukan selama 2 minggu diperoleh hasil bahwa warna dari krim tabir surya tidak mengalami perubahan warna, sedangkan aroma dari krim tabir surya tidak mengalami perubahan aroma.

Uji $\mathrm{pH}$ adalah parameter yang digunakan untuk meningkatkan tingkat keasaman larutan. Uji ini dilakukan untuk mengetahui apakah terdapat perubahan pH dari sediaan krim tabir surya ekstrak anggur hitam selama proses penyimpanan. Hasil pada table 4.4 dianalisis menggunakan analisis sidik ragam untuk 
melihat kestabilan $\mathrm{pH}$ krim tabir surya ekstrak anggur hitam selama 2 minggu. Dari hasil perhitungan maka didapatkan bahwa $\mathrm{F}$ tabel lebih kecil dari $\mathrm{F}$ hitung yang berarti data $\mathrm{pH}$ dari hari pertama sampai dengan hari ke lima belas berbeda tidak nyata pada taraf signifikan $5 \%$. Adanya perbedaan tersebut disebabkan karena kandungan dari anggur hitam tersebut yaitu vitamin $\mathrm{C}$ yang mudah teroksidasi. Namun semua nilai $\mathrm{pH}$ krim tabir surya ekstrak anggur hitam yang diperoleh selama penyimpanan 2 minggu yaitu 5,11, 5,13 dan 5,23 masuk dalam range $\mathrm{pH}$ krim untuk kulit yaitu 4,0-6,0.

Krim tabir surya dalam penelitian ini merupakan sediaan krim dengan tipe $\mathrm{M} / \mathrm{A}$, dimana dalam basis krim terdapat lebih banyak fase air daripada fase minyak karena akan lebih mudah dibersihkan dan menguapnya air dapat menyegarkan jaringan.

Senyawa flavonoid yang terkandung dalam ekstrak anggur hitam dapat berkhasiat sebagai tabir surya. Jika senyawa tabir surya dioleskan pada kulit dan disinari oleh sinar matahari, maka sinar Ultra Violet tidak sampai menembus kulit karena terserap oleh bahan tabir surya, jika bahan tabir surya terpancar sinar matahari terus menerus akan terjadi proses inaktivasi dari bahan tabir surya tersebut, sehingga pada waktu tertentu bahan tabir surya tidak lagi mampu menyerap secara efektif sinar matahari. Oleh karena itu untuk mendapatkan perlindungan yang maksimal penggunaan tabir surya sebaiknya terus diulang beberapa kali selama kulit terkena pancaran sinar matahari.

\section{KESIMPULAN}

Berdasarkan hasil yang diperoleh maka dapat disimpulkan sebagai berikut :

1. Ekstrak anggur hitam memiliki khasiat sebagai tabir surya yang berfungsi sebagai pelindung kulit dari efek buruk sinar matahari.

2. Semua konsentrasi ekstrak anggur hitam yang digunakan dalam penelitian ini dapat memberikan efek sebagai antioksidan, namun konsenstrasi yang paling besar memberikan efek sebagai antioksidan adalah $1,2 \%$ yaitu 2,53 .

\section{DAFTAR PUSTAKA}

[1]. Retno, IT.2007. Buku Pegangan Ilmu Pengetahuan Kosmetik. PT. Elexa Pustaka: Jakarta.

[2]. Sjarif, M. 1997. Penuntun Ilmu Kosmetik Medik. Universitas Indonesia: Jakarta.

[3]. Ardiansyah. 2007. Antioksidan dan Peranannya bagi Kesehatan. Artikel Tohoku University Sendai: Jepang. 1-4

[4]. Teuku, N. 2008. Teknologi Formulasi Sediaan Semi Padat. UGM Press: Yogyakarta.

[5]. Refjellinec, JS. 1970. Formulastion and Function of Cosmetic. New York.

[6]. Ayu, U. 2009. Identifikasi Hidrokuinon Dalam Krim Pemutih Kulit Selebritis Night Cream Dengan Metode Kromatografi Lapis Tipis. Universitas Sumatera Utara.

[7]. Medan, Wijaya.H.M. 1992. Tanaman Berkhasiat Obat di Indonesia Ed.I. Jakarta.

[8]. Anief, M. 2007. Ilmu Meracik Obat. Gadjah Mada Unversity Press: Yogyakarta. 71-72

[9]. Anief, M. 1993. Farmasetika. Gadjah Mada University Press: Yogyakarta. 116-117.

[10]. Avianti, R dan Anastasia, A. Cantik Dengan Buah. Prevention Indonesia: Jakarta.

[11]. Bunawas. 1999. Radiasi Ultraviolet dari Matahari dan Resiko Kanker. Pusat Standarisasi dan Penelitian Keselamatan Radiasi, Badan Tenaga Atom Nasional: Jakarta. 1-4

[12]. Haryanto, S. 2009. Ensiklopedia Tanaman Obat Indonesia. Pallmall: Yogyakarta

[13]. Ditjen POM ( 1995). Farmakope Indonesia. Edisi IV. Jakarta: Departemen Kesehatan R.I 
[14]. Utami, P. 2008. Buku Pintar Tanaman Obat. PT. Agromedia Pustaka: Jakarta. 13

[15]. Sudjardi. 1986. Metode Pemisahan. Universitas Gadjah Mada Press: Yogyakarta.

[16]. Syamsuni, A. H. 1997. Ilmu Resep. Gadjah Mada University Press. Yogyakarta. 71-72

[17]. Ansel, C.H. 1989. Pengantar Bentuk Sediaan Farmasi Terjemahan Farida Ibrahim Edisi IV. Universitas Indonesia Press: Jakarta. 496, 515, 523.

[18]. Kartodidjojo, S. 1988. Pedoman Pengujian Sediaan Rias. Pusat Pemeriksaan Obat dan Makanan Direktorat Jenderal Pengawasan Obat dan Makanan. Departemen Kesehatan Republik Indonesia: Jakarta. 17

[19]. Balsam, M.S. 1972. Cosmetic Science and Technology Second. Edition Vol 1. Wiley Intersience; New York. 55, 450, 510.

[20]. Adhi, J. 2002. Ilmu Penyakit Kulit dan Kelamin. Edisi III. Fakultas Kedokteran Universitas Indonesia: Jakarta.
[21]. Alif, H. 2000. Kapita Selekta Kedokteran. Jilid II. Fakultas Kedokteran Universitas Indonesia: Jakarta.

[22]. Mulyana, M dan Syahrani, A. 1990. Aplikasi Analisis Spektrofotometri UV-Vis. Mecphiso Grafika: Surabaya. 1-84.

[23]. Ditjen POM. 1979. Farmakope Indonesia Edisi III. Universitas Indonesia Press: Jakarta

[24]. Kibbe, A.H. 2000. Handbook of Pharmaceutical Exipients. Edisi III. American Pharmaceutical Association and Pharmaceutical Press: USA

[25]. Husniah, R.T.A. 2008. Peraturan Kepala Badan Pengawas Makanan RI Tentang Bahan Kosmetik. Badan POM RI. 3-4

[26]. Wibisono, Y. 2009. Metode Statistika. Gadjah Mada University Press: Yogyakarta.

[27]. Hardjono. 2005. Spektroskopi. Universitas Gadjah Mada: Yogyakarta.

[28]. Arikunto, S. 2006. Prosedur Penelitian Suatu Pendekatan Praktik. Edisi Revisi VI. PT. Rineka Cipta: Jakarta 